\title{
Commentary on the "Fundamental Values" Controversy
}

\author{
Geoffrey C. Hazard, Jr. ${ }^{\dagger}$
}

Law is not self-defining. If it were, judges and lawyers would not be needed to expound it. Constitutional authority, whatever it is, and by whomever it is expounded, is authority prescribed by law. It follows that constitutional authority is not self-defining, and that the authority of the expounders of constitutional law-the Supreme Courtis not self-defining. That brings us back to square one, to a search for external definition of the constitutional authority of the Supreme Court.

The search drives itself in various directions. One is to the text of the Constitution. An example of this pathway is that taken by Mr. Berger-I mean Raoul. ${ }^{1}$ But, of course, the text is not self-defining. Another quest is that which searches for the "intent" of the Framers. The same consequence ensues. "Intent" of legislative authors is no more self-defining than the text, and is usually less so.

Characteristically, the search proceeds to higher law-natural lawas a limit on authority as well as a source of authority. So it was in the Middle Ages, so it was in the time of the Stuart kings, so it is in the "fundamental values" controversy. So it is, one might even say, in the search for "neutral principles."2 And so it shall be forever and ever.

But natural law is not self-defining either, as Professor Brest's magisterial exposition well shows. For who is the authoritative expounder of natural law in any of its formulations? It used to be God, but He is now dead, or perhaps living in the Sun Belt. In any case He speaks in many tongues-as the Ayatollah has recently demonstrated. "Natural law," "fundamental values," "neutral principles," "preferred positions" -all are formulations that exclude while they include, and so imply alternatives, and so are not peremptory in any ultimate sense.

$\dagger$ John A. Garver Professor of Law, Yale University.

1. See R. Berger, Congress v. The Supreme Court (1969).

2. See Wechsler, Toward Neutral Principles of Constitutional Law, 73 HARv. L. REv. 1 (1959). 
If we can discover no ultimate normative premises, does it follow that there is no foundation for constitutional authority, and that we are therefore consigned to government by caprice? That may be the implication of regarding the Supreme Court as a legislature, a suggestion I made in a widely disregarded article. ${ }^{3}$ If we cannot find an authoritative norm upon which to hang the Supreme Court's authority, do we have anything to hang onto?

One possibility, expressed at the end of Professor Brest's paper, is that of social contract. The social contract in this case is that which has been negotiated between a succession of Justices and a succession of other plenipotentiaries: Marshall and Jefferson on the judicial establishment; Marshall and Jackson-"John Marshall has made his decision, now let him enforce it"; Taney and the first Senator Douglas from Illinois and Lincoln, who had conversations on the subject of equality; the Justices who wrote the income tax cases and the politicians who carried the Sixteenth Amendment; Franklin Roosevelt and Charles Evans Hughes; Richard Nixon, Sam Ervin, and the present Court.

Those negotiations involve positioning, claiming, offering, threatening, retreating, agreeing, combining, and so on-complex maneuvers and signals over time. That process begins with the recognition that the means of conferring political authority and responsibility are not exhausted, and, indeed, are barely introduced, by the notion of selection through the electorial process. In the various means of conferring political authority and responsibility, there is an awareness that force and violence, the final political currency of the ever-feared proletariat, are elements of political interaction. Wealth, the political currency of the ever-feared oligarchy, is also an implement of politics. We can call the dynamics of these fundamental elements "checks and balances," as the Founders did, or we can use the terminology of a somewhat later political philosopher-thesis, antithesis, and synthesis.

Such a view of political authority has no teleological content. It does not reveal the future for us, which is perhaps what we really wanted all along in our search. But it is, at least, intelligibly existentialist.

Obviously, such a view of constitutional authority enlarges the field of constitutional scholarship to a much wider domain than it has conventionally occupied, as Professor Brest has indicated. That is welcome. But if we examine that larger domain, we discover it to be politics considered inclusively and not the limited precincts encompassed

3. Hazard, The Supreme Court as a Legislature, 64 CoRnetc L. REv. 1 (1978). 
by traditional constitutional scholarship. It is a scandal that traditional constitutional scholarship has defined itself so narrowly.

The larger terrain is not only very large, it is messy and noisy. It has no refuge for wholly disengaged scholarship, for scholarship as we know it is one of the contending political forces. ${ }^{4}$ In this connection, I must observe that my perspective has been shaped by my professional experience. Unlike most contributors to the literature surveyed $\mathrm{ky}$ Professor Brest, I spent my professional apprenticeship in the legislative process and not in a judicial clerkship. Since then, $I$ have spent most of my idle hours writing legislation rather than constitutional commentary. From this perspective, it is interesting to contemplate concerns about the value preferences of the Supreme Court, and about the democracy of its law making. Perhaps those who accept direct participation in law making as the highest political value ought to try it sometime.

4. Cf. Brown v. Board of Educ., 347 U.S. 483, $494 \mathrm{n} .11$ (1954) (references to social science scholarship); Erie R.R. v. Tompkins, 304 U.S. 64, 72 nn.3-4, 73 nn.5-6, 74 nn.7.8 (1938) (references to legal scholarship). 